\title{
TAIXU, YOGĀCĀRA, AND THE BUDDHIST APPROACH TO MODERNITY
}

\author{
Scott Pacey, The University of Manchester
}

Taixu 太虛 (1890-1947) is one of the most important Chinese Buddhist monastics of the twentieth century. He is known chiefly for his attempts to demonstrate the relevance of the dharma ( $f a$ 法; the Buddha's teachings) to the intellectual landscape of the post-May Fourth era. To underscore the dharma's resonance with scientific and ideological trends in an intellectual context antagonistic to religion, Taixu presented his views under the rubric of "Buddhism for human life" (rensheng Fojiao 人生佛教; a term he introduced in 1928), ${ }^{1}$ and later (from 1933), ${ }^{2}$ "Buddhism for the human world" (renjian Fojiao 人間佛教). Although he ultimately judged his reform efforts to have failed, ${ }^{3}$ his ideas became increasingly influential after his death and eventually entered into mainstream Buddhist discourses in China and Taiwan.

I gratefully acknowledge the support I received from the Australian Friends of the Hebrew University and the Louis Frieberg Center for East Asian Studies, when I was a Golda Meir Postdoctoral Fellow at the Hebrew University of Jerusalem in 2011-13.

${ }^{1}$ See Taixu 太虛, “Duiyu Zhongguo Fojiao geming seng de xunci 對於中國佛教革命僧的訓詞” (Instructions to Chinese Buddhism's Revolutionary Clergy), in Taixu dashi quanshu 太虛大師全書 [TDQS] (The Complete Works of Master Taixu) (CD-ROM), ed. Yinshun 印順, vol. 17 (Xinzhu: Caituan faren Yinshun wenjiao jijinhui (2005 [1928]), p. 597.

${ }^{2}$ See Taixu, “Zenyang lai jianshe renjian Fojiao 怎樣來建設人間佛教” (How to Establish Buddhism for the Human World), in TDQS, vol. 24 (2005 [1933]), p. 431.

${ }^{3}$ See Taixu, “Wo de Fojiao geming shibai shi 我的佛教革命失敗史” (The History of the Failure of My Buddhist Revolution), in TDQS, vol. 29 (2005 [1937]), pp. 61-63. 
Although Taixu typically discussed Buddhism from a variety of different angles, Yogācāra often featured in his efforts to demonstrate to intellectuals that Buddhism could further their modernist projects. In a study of Taixu's views on Yogācāra, Li Guangliang points out that "although Taixu promoted Yogācāra, he did not endorse using Yogācāra doctrines to reconstruct Chinese Buddhism. His intention was merely to turn Yogācāra into one resource in the development of Chinese Buddhism." "Taixu was not alone in taking this approach—other Buddhists during his career also considered Yogācāra capable of mounting an effective Buddhist response to Western scientific disciplines and thought. ${ }^{5}$ According to them, Yogācāra, like science, addressed the nature of the noumenon, discussed epistemology and causality, and had a system of logic. ${ }^{6}$ For Taixu, these positive correlations with Western modernity were evidence of Buddhism's veracity. At the same time, he maintained that Buddhism could expose and rectify inadequacies in contemporary Western science, philosophy, and ideology. It therefore warranted serious intellectual attention from intellectuals who were interested in these ideas.

This chapter will show that Yogācāra played an important role in Taixu's presentation of Buddhism as modern, even though he himself maintained an essentially conservative doctrinal position. He understood modernity as referring to ideas that originated in Euro-America. Countries that were "individualistic" or "socialistic," that were "scientifically developed," and

\footnotetext{
${ }^{4}$ Li Guangliang 李廣良, Xinshi de liliang: Taixu weishixue sixiang de yanjiu 心識的力量: 太虛唯識學的研究 (The Strength of Consciousness: Research on Taixu's Yogācāra) (Shanghai: Huadong shifan daxue chubanshe, 2003), p. 48.

${ }^{5}$ Chen Bing 陳兵 and Deng Zimei 鄧子美, Ershi shiji Zhongguo Fojiao 二十世紀中國佛教 (Twentieth-Century Chinese Buddhism) (Beijing: Minzu chubanshe, 2000), pp. 227-228.

${ }^{6} \mathrm{Li}$, Xinshi de liliang, pp. 22-24.
} 
that had already passed through a phase of "industrial revolution" were modern in this sense. ${ }^{7}$ For Taixu, modernity therefore entailed coherence with current trends of Western origin. On this basis, the following analysis will focus on his use of Yogācāra in discussions of contemporary science and Western philosophy, including social evolution, psychology, the theory of relativity, biology, and the reformation of the individual. The chapter will draw on Taixu's writings and speeches from the time of the May Fourth movement in 1919, with its calls to replace religion with science and democracy, through to the 1930s.

The focus of the chapter, however, will be on Taixu's writings from the 1920s. While this period saw the rise of an antireligious movement associated with Marxism, other aspects of the time made it hostile to religion as well. The Guomindang (GMD), which formed a national government in 1927, assumed that "society was knowable and changeable by science," and "that history was moving toward a new stage in which the harmful legacies of the past (especially ignorance and superstition) could be dealt a fatal and definitive blow." ${ }^{\prime 8}$ Beginning in the early twentieth century, "'science' often came to be the touchstone in dividing between 'religion' (compatible with science) and 'superstition' (unscientific), so that the three formed a triangle in modernist rhetoric." ${ }^{9}$ Within this context, demonstrating Buddhism's coherence with science was necessary if it was to gain intellectual and political acceptance.

\footnotetext{
${ }^{7}$ Taixu, “Zenyang jianshe xiandai Zhongguo de wenhua 怎樣建設現代中國的文化” (How to Establish a Modern Chinese Culture), in TDQS, vol. 20 (2005 [1935]), p. 125.

${ }^{8}$ Vincent Goossaert and David A. Palmer, The Religious Question in Modern China (Chicago and London: University of Chicago Press, 2011), p. 62.

${ }^{9}$ Ibid., p. 50.
} 
Taixu's discussions of the similarities between Buddhism and modern ideas from the West were therefore expedient, but also reflected his firm beliefs. ${ }^{10} \mathrm{He}$ located a model for Buddhism's modernization in Sun Yat-sen's “Three Principles of the People” (Sanminzhuyi 三民 主義)—the driving ideology of the GMD—which he considered to have successfully merged traditional Chinese culture with modernity. ${ }^{11}$ Like Sanminzhuyi, Taixu thought that Buddhism could adapt to new contexts while preserving its unchanging, fundamental tenets. ${ }^{12}$ The multidimensional nature of his engagement with the world of non-Buddhist ideas, some of which were antithetical to religion, thus points to the complexity of Taixu's thought, and suggests that he should be considered more than an exclusively Buddhist thinker.

Taixu's views were forged in opposition to the atheistic tendencies of the 1920s. In 1922, the Anti-Christian Student Federation (Feijidujiao xuesheng tongmeng 非基督教學生同盟), and an outgrowth of this organization, the Anti-Religion Federation (Feizongjiao tongmeng 非宗教 同盟), had opposed the World Student Christian Federation (Shijie Jidujiao xuesheng tongmeng 世界基督教學生同盟) meeting in Beijing. ${ }^{13}$ The years 1923 and 1924 also saw the beginning of a debate between advocates of science and those of metaphysics concerning which was most

${ }^{10}$ Taixu, “Rensheng Foxue de shuoming 人生佛學的說明” (An Explanation of Buddhism for Human Life)," in TDQS, vol. 3 (2005 [1928]), p. 209.

${ }^{11}$ Ibid., p. 208. Taixu identified his own plans for Buddhist reform with those of Sanminzhuyi. See Don A. Pittman, Toward a Modern Chinese Buddhism: Taixu's Reforms (Honolulu: University of Hawai'i Press, 2001), p. 169. For Taixu’s original discussion, see Taixu, "Duiyu Zhongguo Fojiao geming seng de xunci," pp. 598-604.

${ }^{12}$ Taixu, “Xin yu rongguan 新與融貫” (The New and the Blended), in TDQS, vol. 1 (2005 [1937]), p. 450.

${ }^{13}$ See Tatsuro Yamamoto and Sumiko Yamamoto, "II. The Anti-Christian Movement in China, 1922-1927," The Far Eastern Quarterly 12, no. 2 (1953): 133-147; Douglas Lancashire, "Introduction," in Chinese Essays on Religion and Faith, trans. Douglas Lancashire (Hong Kong: Chinese Materials Center, 1981), pp. 6-10. 
suited to the formation of a viable "philosophy of life." ${ }^{14}$ Zhang Junmai 張君勱 (1886-1969) led the metaphysicians in this debate, arguing that science did not embody a moral outlook. They were opposed by thinkers such as Ding Wenjiang 丁文江 (1887-1936), Chen Duxiu 陳獨秀 (1879-1942), and Hu Shi 胡適 (1891-1962), ${ }^{15}$ who argued that science did embody a worldview — one in which "the outlook on life is reduced to science" and "the evaluation of good and evil is also reduced to scientific cognition."16

Perhaps as a response to these intellectual currents, at a 1928 lecture in Paris, Taixu explained that Buddhism shared similarities with science, religion, and philosophy, but also that it was different from them. ${ }^{17}$ However, he also stressed throughout his career that Buddhism encompassed much scientific knowledge. Its compatibility with science and its provision of a moral framework thus resolved the dilemma faced by intellectuals in 1923 and 1924, and meant that Buddhism was well placed to serve as the worldview for modern society. His writings on Yogācāra were integral to his demonstration of this, as well as to his broader project aimed at establishing a preeminent place for Buddhism on the intellectual landscape of modern China more generally.

\section{The New Yogācāra}

${ }^{14}$ Danny Wynn Ye Kwok, Scientism in Chinese Thought 1900-1950 (New Haven, CT: Yale University Press, 1965), p. 135 .

${ }^{15}$ Ibid., p. 150.

${ }^{16}$ Yang Guorong, "The Debate between Scientists and Metaphysicians in Early Twentieth Century: Its Theme and Significance," Dao: A Journal of Comparative Philosophy 2, no. 1 (2002): p. 4.

${ }^{17}$ Taixu, “Foxue yu kexue zhexue ji zongjiao zhi yitong 佛學與科學、哲學及宗教之異同” (The Differences and Similarities between Buddhism, Science, Philosophy and Religion), in TDQS, vol. 20 (2005 [1928]), p. 19. 
Although Taixu argued that Buddhism was aligned with modernity, his stance on Yogācāra was essentially traditional. Chinese Buddhists had two terms for Yogācāra at their disposal: Weishi 唯識 (nothing but consciousness), which emphasized cognitive processes; and Faxiang 法相 (dharma characteristics) — a derogatory name used by exegetes of the Huayan School (Huayan zong 華嚴宗) who regarded Yogācāra scholars as focusing narrowly on “the superficial manifestations of things." ${ }^{18}$ In contrast to his prominent contemporary Ouyang Jingwu 歐陽竟無 (1871-1943), whom Eyal Aviv discusses in detail this volume, Taixu opposed the division of Faxiang and Weishi, stating that "their content is fundamentally the same." ${ }^{\prime 19}$ He thus frequently combined the two terms. In 1933, he explained that

the conjoined terms, "Faxiang" and "Weishi," express the fact that the mind manifests all dharmas: the "five kinds of dharmas" (wu fa 五法), ${ }^{20}$ the "three aspects" (san xiang 三 相 $)^{21}$ and so on. [The term] “wei 唯” means “not detached." “Shi 諳” refers to the fact that of the one hundred dharmas (bai fa 百法), in addition to the eight consciousnesses

\footnotetext{
${ }^{18}$ A. Charles Muller, “Translator's Introduction,” in Shun'ei Tagawa, Living Yogācāra: An Introduction to Consciousness-Only Buddhism, trans. A. Charles Muller (Boston, MA: Wisdom Publications, 2009), p. xxi. The Huayan School, which privileged the teachings of the Avatamsaka-sūtra (Huayan jing 華嚴經; Flower Ornament Sutra), stressed the interdependence and relativity of phenomena.

${ }^{19}$ Ibid., p. 20. Taixu, “Faxiang weishixue gailun 法相唯識學概論” (An Overview of Dharma-CharacteristicsConsciousness-Only), in TDQS, vol. 9 (2005 [1932]), p. 1151.

${ }^{20}$ Here, Taixu probably means the five skandhas.

${ }^{21}$ Arising, abiding, and ceasing.
} 
(ba shi 八識) and the fifty-one mental associates/factors (wushiyi xin 五十一心所), ${ }^{22}$ the other forty-one dharmas cannot exist detached from the mind either. ${ }^{23}$

In holding these views, Taixu did not advocate any radically new doctrinal interpretations; in general he upheld a position founded on Xuanzang's 玄牀 (602-664) Cheng weishi lun 成唯識 論 (Demonstration of Nothing but Consciousness) and Kuiji’s 窺基 (632-682) Cheng weishi lun shuji 成唯識論述記 (Commentary on the Cheng weishi lun). ${ }^{24}$

Taixu also differed with Ouyang over how to interpret Dasheng qixin lun 大乘起信論 (Awakening of Mahāyāna Faith). He considered this to be a legitimate Indian text even though serious doubts had been raised concerning its traditionally accepted history - that it was composed by Aśvaghoșa 馬鳴 (ca. 80-150) and translated into Chinese from Sanskrit by

${ }^{22}$ See the detailed description in John Powers's chapter in this volume.

${ }^{23}$ Taixu, “Faxiang weshixue gailun,” pp. 1165-1166; Digital Dictionary of Buddhism, s.v. “baifa 百法,” by C. Muller, http://buddhism-dict.net/ddb>.(accessed June 23, 2011):

According to the Yogācāra 唯識 school, all experiential phenomena are divided into the five categories of: mind 心, mental factors 心所, form 色法, factors not directly associated with mind 心不相應行法, and unconditioned dharmas 無爲法. In mind group there are eight; within mental factors there are fifty-one, among which are the five which function pervasively 五遍行, the five that function only in regard to specific objects 五別境, the eleven good factors 十一善, the six primary afflictions 根本煩惱, the twenty secondary afflictions 隨煩惱 and the four indeterminate dharmas 四不定. In the group of form there are ten, in the group that are not directly associated with mind, there are twenty-four, in the unconditioned, there are six 六無爲, totaling one hundred.

${ }^{24} \mathrm{Li}$, Xinshi de liliang, 163. 
Paramārtha 眞諦 (500-569). ${ }^{25}$ For example, in his study of the text, Liang Qichao 梁啟超 (1873-1929) concluded that it was of Chinese origin. ${ }^{26}$

In addition, whereas the Dasheng qixin lun held that Suchness and reality were entwined and that Suchness could be perfumed, Ouyang maintained that Suchness and reality were separate. ${ }^{27}$ In other words, Ouyang's "assumption that there are two separate worlds, the world of higher or 'real' truth versus the world of inferior or 'worldly' truth, or the development of dharma-nature versus the world of dharma-character," could not be reconciled with the Dasheng qixin lun's position: that these two worlds were "merely the two aspects of the same thing." 28 Taixu's acceptance of the Dasheng qixin lun's basic position, however, like his equation of Faxiang and Weishi, marked him as an upholder of the Chinese Buddhist tradition.

Taixu did, however, believe that a new approach to Yogācāra was necessary in the modern era. In a 1920 speech, he explained that this was because

recent scientific advances have achieved extraordinary results, and theistic religion has completely lost its basis. Science has gradually occupied the domain of philosophy. The only path remaining for philosophy now is one of metaphysics ... [however] doubt now

${ }^{25}$ Francesca Tarocco, "Lost in Translation? The Treatise on the Mahāyāna Awakening of Faith (Dasheng qixin lun) and Its Modern Readings," Bulletin of the School of Oriental and African Studies 71, no. 2 (2008): 323-343.

${ }^{26}$ Ibid., 333.

${ }^{27}$ Wing-Tsit Chan, Religious Trends in Modern China (New York: Columbia University Press, 1953), p. 114.

${ }^{28}$ Ibid., pp. 114-115. 
exists that metaphysics can offer us anything in the way of knowledge, or that what it can know is useless. ${ }^{29}$

Although Taixu clearly recognized the importance of science, like many Chinese intellectuals of the post-World War I generation, he traced the source of conflict to its misuse. In the absence of philosophy and theism, something else was needed to guide scientific inquiry so that it could be used for peaceful and constructive purposes. He suggested that while Yogācāra could make substantial contributions in this regard, ${ }^{30}$ it would need to be presented in ways that accorded with twentieth-century intellectual trends. He therefore called for Yogācāra to be discussed using scientific terminology ${ }^{31}$ and referred to this as the "new Yogācāra.",32

Aside from advocating a new mode of expression, the content of Yogācāra would remain the same. According to Wing-Tsit Chan,

Taixu calls his theory new because, he says, it is elucidated with modern ideas, makes use of modern science, and agrees with Einstein's Theory of Relativity. . . . Actually, his understanding of Western philosophy is extremely superficial. And he has not offered a new theory of ideation. ${ }^{33}$

Although Taixu's views on Yogācāra may not have been doctrinally innovative, the links he identified between Yogācāra and non-Buddhist ideas caused him to conceive of it in unique ways.

\footnotetext{
${ }^{29}$ Taixu, “Xin de weishilun 新的唯識論” (A Treatise on the New Yogācāra), in TDQS, vol. 8 (2005 [1920]), p. 606.

${ }^{30}$ Ibid., p. 607.

${ }^{31}$ Ibid., p. 610.

32 Ibid.

${ }^{33}$ Chan, Religious Trends in Modern China, pp. 124-125. Romanization modified.
} 
When he went into sealed confinement for three years on Putuo Mountain from $1914,{ }^{34}$ he took works on Yogācāra with him, demonstrating the importance he attached to the school during these early phases of his intellectual development. ${ }^{35} \mathrm{He}$ also took books on "psychology, logic, ethics, and philosophy." 36

In the years prior to Taixu's confinement, he had also read numerous works that embodied the ideals of science and progress. These included Zhang Taiyan's 章太炎 (18681936) “Jianli zongjiao lun 建立宗教論” (Founding a Religion), ${ }^{37}$ Kang Youwei’s 康有為 (1858-1927) Datong shu 大同書 (Book on the Great Unity), Tan Sitong's 譚嗣同 (1865-1898) Renxue 仁學 (An Exposition of Benevolence), and Liang Qichao's Xinmin shuo 新民說 (On the New Citizen), ${ }^{38}$ as well as works by Tolstoy, Kropotkin, Bakunin, Proudhon, Marx, and Kōtoku Shūsui. ${ }^{39}$ He also read Yan Fu's 嚴復 (1854-1921) 1903 translation of Herbert Spencer’s The Study of Sociology (Qunxue siyan 群學肆言). ${ }^{40}$ Taixu's subsequent work bore the legacy of these early influences and demonstrated his belief that Buddhism had important links to science and society, while also critiquing them from his Buddhist standpoint.

\footnotetext{
${ }^{34}$ Taixu, “Taixu zizhuan 太虛自傳” (Autobiography of Taixu), in TDQS, vol. 29 (2005 [1940]), p. 208.

${ }^{35}$ Chan, Religious Trends in Modern China, p. 119.

${ }^{36}$ Taixu, “Taixu zizhuan,” p. 209.

${ }^{37}$ Taixu, “Wo de Fojiao gaijin yundong lüeshi 我的佛教改進運動略史” (A Brief History of My Buddhist Reform Movement), in TDQS, vol. 29 (2005 [1940]), p. 74.

${ }^{38}$ Taixu, “Taixu zizhuan,” p. 191.

${ }^{39}$ Ibid., 194.

${ }^{40}$ Taixu, “Wo de Fojiao gaijin yundong lüeshi,” p. 69.
} 


\section{The scientific method}

The links between science and Buddhism can be seen from Taixu's discussions of one of the pillars of Western modernity: the scientific method itself. Although he considered the scientific method to be flawed, he also believed that it could be improved on through the introduction of concepts from Yogācāra. The underlying problem with the scientific method was that it relied on the imperfect observations of deluded beings. For example, in a 1919 piece entitled "Materialist Science and the Study of Yogācāra," he explained that research on optics and electricity had shown all phenomena to consist of impermanent false forms (jiaxiang 假相) that were in a continual state of flux. ${ }^{41}$ Although science had verified this, Yogācāra would provide a basis for it to be perceived more directly through the five eyes (wuyan 五眼) ${ }^{42}$ With one of these, the buddha eye (foyan 佛眼), one would be able to see that everything is of one mind (yixin 心), and the “two characteristics" (er xiang 二相 $)^{43}$ would disappear. ${ }^{44}$

Furthermore, in 1924, he explained that scientific observations did not take the relationship between the mind and the phenomenal world into account. As a result, the theories scientists developed on the basis of their observations were misguided. ${ }^{45}$ Despite this, Taixu also

${ }^{41}$ Taixu, “Weiwu kexue yu weishi zong xue 唯物科學與唯識宗學” (Materialist Science and the Study of Yogācāra), in TDQS, vol. 22, 2005 [1919], p. 818.

${ }^{42}$ Ibid., p. 819. The five eyes is a notion taken from Yogācārabhūmi-śāstra (Yuqie shidi lun 瑜伽師地論; Discourse on the Stages of Concentration Practice): the physical eye; the heavenly eye; the wisdom eye, the dharma eye; and the buddha-eye.

${ }^{43}$ The universal and particular characteristics of Suchness.

${ }^{44}$ Taixu, "Weiwu kexue yu weishi zong xue," p. 819.

${ }^{45}$ Taixu, “Renshengguan de kexue 人生觀的科學” (The Science of the Philosophy of Life), in TDQS, vol. 23 (2005 [1924]), pp. 4-5. 
criticized the basis of science in materialism, stating that "the three worlds are nothing but mind [weixin 唯心], the ten thousand dharmas are nothing but consciousness [weishi 唯識]. ${ }^{46}$ In the absence of Yogācāra, scientists were thus faced with two problems: first, their reliance on flawed observation; and second, their false understanding of the phenomenal world and its relation to cognition.

Taixu did accept that science and Buddhism were different; whereas science presented a method he characterized as "narrow," $" 47$ Buddhism constituted a "broad scientific method."48 Both approaches, however, were useful and pursued truth from different levels of depth: "Buddhism's explanations are deep but its level of detail is shallow," whereas "science's explanations are shallow but its level of detail is deep." ${ }^{\prime 49}$ Taixu therefore saw the future of Yogācāra and science as one in which they could complement one another. ${ }^{50}$ In time, scientists would come to appreciate Buddhism's explanatory power. He provided a further example of this by stating that among the "worldly methods of seeking knowledge, science is more excellent," but that Buddhism could "improve" the "six senses and eight consciousnesses," increasing one's capacity to observe reality directly, ${ }^{51}$ thus leading to improved scientific observations. This led Taixu to suggest that in the future, "Yogācāra methods could . . . increase the limited powers of

\footnotetext{
${ }^{46}$ Ibid., p. 813 .

${ }^{47}$ Taixu, "Renshengguan de kexue," p. 6.

${ }^{48}$ Ibid., p. 5.

${ }^{49}$ Taixu, “Yue Weishi xin lun jianshu 閱“唯識新論’簡述” (A Concise Account of My Reading of “A New Treatise on Yogācāra”), in TDQS, vol. 25 (2005 [1935]), p. 169.

${ }^{50}$ Taixu, “Xin de weishi lun,” p. 610.

${ }^{51}$ Taixu, “Zhen xianshilun zongyilun (shang) 真現實論宗依論（上）（On True Realism: On the School’s Basis [Part 1])," in TDQS, vol. 18 (2005 [1927]): p. 159.
} 
telescopes and microscopes." 52 Yogācāra would improve on the scientific method, augmenting scientists' powers of observations so that they could use their scientific instruments to full effect.

\section{Biology}

As might be expected from this comment, Taixu also considered Buddhist texts to embody knowledge on microbiology. Erik J. Hammerstrom has shown how the effort to demonstrate the Buddha's awareness of microbiological science led Taixu to search for evidence in lesser-known texts, thus promoting them to new positions of prominence. ${ }^{53}$ In 1919 and 1923 , he referred to a phrase from the Pini riyong lü 毗尼日用綠 (Record of the Vinaya for Daily Use) to show that the Buddha was aware of the existence of microorganisms - before Antonie van Leeuwenhoek's (1632-1723) observation of them in the seventeenth century. Taixu also used a citation from the Saddharma-smrty-upasthāna-sūtra (Zhengfa nianchu jing 正法念處經; Sutra on the Bases of Mindfulness of the True Dharma) as evidence that the Buddha had knowledge concerning the existence of gametes and cells. The notion that the Buddha had advanced microbiological knowledge later became a common theme in the 1920s.

While Buddhism embodied existing biological knowledge, Yogācāra could be used to fill gaps in our understanding of processes such as reproduction. In 1923, drawing from the Yogācārabhūmi-śāstra (Discourse on the Stages of Concentration Practice), ${ }^{54}$ Taixu explained that it was the base consciousness that in fact enabled male and female gametes to form a zygote,

\footnotetext{
${ }^{52}$ Taixu, "Renshengguan de kexue," p. 54.

${ }^{53}$ Erik J. Hammerstrom, “Early Twentieth-Century Buddhist Microbiology and Shifts in Chinese Buddhism’s 'Actual Canon,'” Theology and Science 10, no. 1 (2012): --18.

${ }^{54}$ On this text, see the "Summary of the Yogācārabhūmi-śāstra" by Dan Lusthaus and Charles Muller, which is available at: www.acmuller.net/yogacara/outlines/YBh-summary-utf8.htm (accessed June 14 2010).
} 
thereby creating the first fetal stage (the first of eight stages of fetal development). ${ }^{55}$ Without this, the gametes would disperse ${ }^{56}$ Further proof, according to Taixu, came from those who had developed the "divine eye" - they had confirmed the Buddhist account of reproduction contained in the Yogāāarabhümi. In contrast, biologists had as yet been unable to observe directly the process of zygote formation. ${ }^{57}$ (In fact, although Taixu may have been unaware, the German zoologist Oskar Hertwig (1849-1922) had observed this process in sea urchins in $1875 .^{58}$ ) Superior methods of Buddhist observation had therefore enabled important biological information to be obtained centuries before the discoveries of Western scientists.

\section{Psychology}

As Hammerstrom shows in this volume, the Wuchang School, with which Taixu was associated, regularly published articles on Buddhism and psychology during the 1920s. As with the scientific method more generally, Taixu saw Yogācāra and psychology as capable of working together, although performing different functions. In a 1924 essay, Taixu suggested that both could be used to "regulate the mind," ${ }^{, 59}$ while Buddhism's ten good deeds (shi shanfa 十善法)

\footnotetext{
${ }^{55}$ On the stages of fetal development, see Digital Dictionary of Buddhism, s.v. “bawei taizang 八位胎藏,” by C. Muller, http://buddhism-dict.net/ddb (accessed July 17, 2010).

${ }^{56}$ Taixu, "Fo yi jin jie 佛疑今解” (A Contemporary Explanation of Buddhist Uncertainty), in Faxiang weishixue 法 相唯識學 (Dharma-Characteristics-Consciousness-Only) (Beijing: Shangwu yinshuguan, 2006 [1923]), vol. 2, p. 417.

${ }^{57}$ Ibid., p. 419.

${ }^{58}$ Ernst Mayr, The Growth of Biological Thought: Diversity, Evolution, and Inheritance (Cambridge, MA: The Belknap Press of Harvard University Press, 1982), pp. 665-666.

${ }^{59}$ Taixu, "Renshengguan de kexue," p. 43.
} 
could moderate the mind and behavior. Furthermore, psychology would be used to explain "the motivations [behind] ethics," and "scientific rationality [would be used to] moderate direct perception. ${ }^{60}$ From the perspective of social ethics, psychology and Yogācāra could clearly work in tandem, with Buddhism taking a lead role in the area of morality, and psychology furnishing research on specific mental functions.

Besides suggesting that psychology and Yogācāra could perform these different roles, Taixu also felt they shared common knowledge regarding the senses and certain cognitive functions. In the context of the 1920s, this was an important verification of Buddhism's compatibility with modern science. He thus explained that the Buddhist five sensory faculties (wu gen 五根) ${ }^{61}$ should be equated with the nervous system. ${ }^{62}$ The first six consciousnesses were the subjects of psychological investigations, whereas the independently arising thinking consciousness (dutou yishi 獨頭意識)—the sixth consciousness—was what psychologists called the “imagination." ${ }^{63}$ Meanwhile, the sensory abilities (shengyi gen 勝意根) were akin to nerves joined to organs, such as the optic or auditory nerves. ${ }^{64}$

Ultimately, however, Taixu claimed that Yogācāra provided a more expansive account of the mind's mental processes than psychology. ${ }^{65}$ Yogācāra's “shi 識,” or “consciousness,” was

\footnotetext{
${ }^{60}$ Ibid.

${ }^{61}$ The visual, hearing, olfactory, gustatory, and tactile faculties.

${ }^{62}$ Taixu, "Faxiang weishixue gailun," pp. 1196-1197.

${ }^{63}$ Ibid., pp. 1189-1190.

${ }^{64}$ Taixu, “Bashi guiju song jianglü 八識規矩頌講錄” (Records of a Lecture on Verses on the Structure of the Eight Consciousnesses), in TDQS, vol. 9 (2005 [1931]), 918.

${ }^{65}$ Taixu, "Faxiang weishixue gailun,” pp. 1189-1190.
} 
broader than the psychological definition (which encompassed only knowledge and emotions). ${ }^{66}$ Moreover, certain aspects of the mind that were unknown to psychologists were well understood in Yogācāra. For example, although psychologists discussed the subconscious and the unconscious, they were unaware of the seventh consciousness-or manas, which erroneously leads us to arrive at the idea of selfhood - and the base consciousness, which is the "storehouse" of our accumulated karma.

In a 1932 piece, Taixu specifically referred to "behavioral psychology" (xingweipai zhi xinlixue 行為派之心理學) and “introspective psychology” (neixing xinlixue 內省心理學), ${ }^{67}$ which were two prominent schools during the period of his career. (A contemporary comparison of the two stated that behaviorism focused on the acquisition of qualitative data on "memory, forgetting, sensation, association, learning, and the like," while introspection focused on "the conscious middle term in the reaction chain and nothing more." ${ }^{68}$ ) According to Taixu, both schools were hindered by their inability to perceive these deep structures of the mind, for which practice in "meditation and wisdom" was required. ${ }^{69}$ Furthermore, the psychological conception of cognition (sixiang 思想) only covered the mind's investigative ( $x u n$ 尋) and scrutinizing (si 伺) functions, or the observation of coarse and fine objects respectively-which was a smaller range of functions than had been identified in Yogācāra. ${ }^{70}$

\footnotetext{
66 Taixu, “Weishi sanshilun jiangyao,” p. 691.

${ }^{67}$ Taixu, "Faxiang weishixue gailun,” p. 1202.

${ }^{68}$ Samuel W. Fernberger, "Behavior versus Introspective Psychology,” The Psychological Review 29, no. 6 (1922):

411.

${ }^{69}$ Taixu, “Faxiang weishixue gailun,” p. 1202.

${ }^{70}$ Taixu, "Bashi guiju song jianglü,” p. 914.
} 
Taixu held that the root of the problem was psychology's basis in materialistic science, which assumed that life was subject to mechanistic laws. ${ }^{71}$ He explained, however, that recent developments in science — such as relativity—-had shown that matter existed only in interdependent relationships. As a result, "old nineteenth-century materialism” was now untenable. ${ }^{72}$ With its detailed discussion of the relationship between the mind and the phenomenal world, Yogācāra was clearly in a position to advance science into the postmaterialistic age.

This approach to scientific explanations of mental functioning distinguished him from a figure who, in many ways, was his predecessor, Tan Sitong. Taixu had read Tan's Renxue (An Exposition of Benevolence) early in his career, and later wrote that he loved it "so much that I could not part with it.",73 Although Tan claimed that all "Western Learning" stemmed from Buddhism, ${ }^{74}$ the emphasis of the book is on the essential agreement between different religious perspectives and branches of science. Whereas Tan had sought to locate Yogācāra's cognitive architecture in the brain, Taixu held that the "physical mind" (routuan 肉團) was merely a "form dharma” (sefa 色法); ${ }^{75}$ that is, an object of sensory perception, rather than the mind itself (xinfa

${ }^{71}$ Taixu, “Fa yu ren zhi yanjiu 法與人之研究” (Research on the Dharma and Human Beings), in TDQS, vol. 9 (2005 [1931]), p. 1321.

72 Taixu, "Fa yu ren zhi yanjiu," p. 1323.

${ }^{73}$ Taixu, “Taixu zizhuan,” pp. 189-191.

74 Tan Sitong, “Renxue,” in Tan Sitong quanji 譚嗣同全集 (The Collected Works of Tan Sitong), ed. Cai Shangsi 蔡尚思 (Beijing: Zhonghua shuju chuban, 1981), vol. 2, p. 317; T'an Ssu-t'ung, An Exposition of Benevolence: The Jen-hsuëh of T'an Ssu-t'ung, trans. Chan Sin-wai (Hong Kong: The Chinese University Press, 1984), p. 107.

${ }^{75}$ Taixu, “She dasheng lun chufen jiangyi 攝大乘論初分講義” (Initial Division of Lectures on the Compendium of the Great Vehicle), in TDQS, vol. 8 (2005 [1925]), p. 502. 
心法) or its mental functions (xinsuo 心所). And even though psychologists assigned memories a physical location within the brain, the brain was too small to store all of them. According to Taixu, the base consciousness provided a superior explanation for the retention of memory. ${ }^{76}$ His approach was thus more closely aligned with that of the more critical Wuchang School.

\section{Social evolution}

While Taixu's early interest in revolutionary social theories had subsided by the 1920 s, his concern with Buddhism's social role remained throughout his life. One of the most important contributions to twentieth-century Chinese Buddhism came in the form of his "Pure Land in the human world" (renjian jingtu 人間淨土) concept in 1926- the notion that rather than focusing on attaining rebirth in the Pure Lands, this world itself could be "purified" by making Buddhism the basis of individual and social life. ${ }^{77}$

As noted above, Taixu indicated in one of his autobiographical accounts that he had read Yan Fu's translation of Herbert Spencer's The Study of Sociology. Yan Fu himself “gravitated to Spencer's side and held that evolution was a law or force that could be generally applied to the domains of nature and social ethics." ${ }^{, 78}$ Displaying the influence of this social Darwinism, Taixu himself proposed an evolutionary scheme that saw Buddhism elevated to become a feature of advanced societies. In doing so, he directly asserted that Buddhism, rather than being the

\footnotetext{
${ }^{76}$ Taixu, "Faxiang weishixue gailun,” pp. 1195-1196.

${ }^{77}$ Taixu coined this term in 1926, although his previous writings display elements of this idea. See Taixu, "Jianshe renjian jingtu lun 建設人間淨土論” (Treatise on Establishing the Pure Land in the Human World), in TDQS, vol. 24 (2005 [1926]), pp. 349-424.

${ }^{78}$ Wang Hui, “The Fate of 'Mr. Science' in China: The Concept of Science and Its Application in Modern Chinese Thought," Positions 3, no. 1 (1995): 25.
} 
outmoded product of a premodern age, in fact surpassed conventional understandings of modernity. It was during such a time that Yogācāra would be treated as a form of "perfect science."

He explained this in some detail in 1927, when he wrote that social evolution's first stage was one of idolatrous semihuman people who were primarily occupied with survival. In the second stage, society was characterized by theistic religion and a system of government. Eventually, theism was discarded in favor of mathematics, ethics, rationality, and science. The third stage saw the rise of what Taixu called the “supermen” (chaoren 超人), who aspired to sagehood and practiced techniques of mental cultivation, such as Chan, Jainism, Yoga, Confucianism, and Daoism. The final stage consisted of the “super-supermen” (chao chaoren 超 超人), who were Buddhists. At this time, the scientific outlook of earlier stages would give way to the study of the various schools of Buddhism: Chan, Pure Land, Huayan, Tiantai, and Yogācāra. During this final stage:

Zhenyan Pure Land studies are a pure aesthetics. Huayan and Tiantai studies are a pure literature. The wisdom that comes from knowing that all dharmas are empty is a pure philosophy. Yogācāra is a pure philosophy, and a pure science. From this it can be seen that the dharma spoken of by the Buddha can encompass everything spoken of by humanity. $^{79}$

Taixu thus situated Buddhism at a higher level than the knowledge systems of the second, scientific stage of civilization, which clearly corresponded with the West. And from among the

79 Taixu, “Zhen xianshilun zongyilun (shang),” p. 159. 
other Buddhist schools, he placed Yogācāra in a privileged position in relation to science, making it the perfect form of modernity's most important feature.

Taixu developed this scheme in opposition to other theories that were attracting attention in the 1920s. One of these belonged to Liang Shuming 梁漱溟 (1893-1988), who, in his influential 1921 book Dongxi wenhua jiqi zhexue 東西文化及其哲學 (Eastern and Western Cultures and Their Philosophies), rejected Buddhism as a suitable basis for society. As Thierry Meynard shows in this volume, although Liang himself was a Buddhist, he chose Confucianism as a middle path between what he considered Western scientific and Indian transcendental culture. Taixu's scheme also contrasted with that of Auguste Comte, who suggested that society passed through "theological," “metaphysical," and "positivist" stages. ${ }^{80}$ (In 1930, Taixu criticized this Comtean scheme on the grounds that it established firm boundaries between religion, philosophy, and science that did not exist, since each one of these categories contained aspects of the others. ${ }^{81}$ ) Taixu's presentation of Buddhism established it as sharing the scientific aspects of Western culture, as well as the worldly aspect of Confucianism. ${ }^{82}$ Encompassing and surpassing both, Buddhism, according to Taixu, was at the peak of the civilizational typologies. As such, Taixu implied that modernists who were interested in science and social progress should turn away from Comte and Liang, as well as from Marxists touting a postreligion future, to embrace Buddhism.

\section{Physics}

\footnotetext{
${ }^{80}$ See George Perrigo Conger, New Views of Evolution (New York: The Macmillan Company, 1929), p. 176.

${ }^{81}$ Taixu, “Minguo yu Fojiao 民國與佛教” (The Republic and Buddhism), in TDQS, vol. 22 (2005 [1930]), p. 1243.

${ }^{82}$ Taixu, “Foxue yu xin sixiang 佛學與新思想” (Buddhism and New Thought), in TDQS, vol. 20, p. 43.
} 
Taixu also claimed that Yogācāra could complete scientific theories concerning more fundamental physical processes. One special target for him in this regard was Einstein's theory of relativity, which had been introduced to China in 1917 by the scientists Xu Chongqing 許崇清 (1888-1969) and Li Fangbai 李芳柏 (1890-1959) after their studies in Japan. ${ }^{83}$ The post-May Fourth intellectual climate provided fertile ground for the theory's popularization. It was praised by Bertrand Russell during his stay in China in 1921, and further popularized by Einstein's own visit in 1922. According to Danian $\mathrm{Hu}$, "Not a single Chinese physicist or mathematician between the 1920 s and the 1940 s publicly opposed the theory. ${ }^{\prime 84}$ Relativity was thus a landmark feature of China's intellectual vista in the 1920s, and given its prominence, to show how Yogācāra could identify the theory's inadequacies and render it complete would have been an astonishing demonstration of Buddhism's modernity.

In 1927, Taixu attempted to do this by responding to an explanation of relativity provided in 1922 by the Scottish naturalist and professor at the University of Aberdeen J. Arthur Thomson (Tang Musheng 湯姆生). Thomson’s explanation had appeared in a four-volume work entitled An Outline of Science, which was published in Chinese in 1923 and 1924 under the title Hanyi kexue dagang 漢譯科學大綱. ${ }^{85}$

\footnotetext{
${ }^{83}$ Danian Hu, “The Reception of Relativity in China," Isis 98, no. 3 (2007): 541.

${ }^{84}$ Ibid., 545.

${ }^{85}$ For the original passage see J. Arthur Thomson (ed.), The Outline of Science: A Plain Story Simply Told, vol. 4 (New York: G. P. Putnam's Sons, 1922), pp. 1032-1033. For the Chinese translation, see Tang Musheng 湯姆生 [J. Arthur Thomson], Hanyi kexue dagang 漢譯科學大綱 (An Outline of Science: Chinese Translation), (Shanghai: Shangwu yinshuguan, 1923-1924), vol. 13 , p. 50.
} 
Thomson explained notions of space, time, and matter with a story about an "intelligence" that, upon arriving in a field, initially lacked these concepts. Eventually, the spirit learned to distinguish between itself and the outside world, creating a dualistic view of reality. When it observed a flower with a wasp on it, the intelligence initially regarded both as part of a unified world external to the self. When the wasp flew into the intelligence's hand, it discovered that there were different points in space, and arrived at concepts such as "here" and "there." After being stung by the wasp, the intelligence also learned about different points in time, and thus gained the ability to distinguish between "before" and "after." Having thus conceptualized space and time, it subsequently went on to develop ideas concerning matter. ${ }^{86}$

Thomson's story was intended to illustrate the principles of relativity. Taixu, however, claimed it was useful for both explaining Yogācāra and simultaneously pointing out the flaws in Einstein's theory:

Although this explanation of the origins of knowledge concerning space, time, and matter has not reached the level of depth of the explanation concerning this origin in the base consciousness, it is near enough! It speaks of a primitive real essence (zhenti 真體 $)^{87}$ —an intelligence completely lacking in experience. We may call this the base consciousness. When it suddenly appears here, it first experiences the environment, and all things within it, as an entirety (quanti 全體). The natural world and the body with senses (genshen 根

\footnotetext{
${ }^{86}$ Taixu, “Ai’ensitan xiangduilun yu Weishilun 愛恩斯坦相對論與唯識論 (Einstein’s Theory of Relativity and Yogācāra)," in TDQS, vol. 21 (2005 [1927]), pp. 616-617.

${ }^{87}$ Digital Dictionary of Buddhism, s.v. “zhenti 真體,” by C. Muller, http://buddhism-dict.net/ddb (accessed March $25,2012)$. This is "the true form of something."
} 
身) appear simultaneously to the base consciousness. The body and the environment are then understood to be two things. Next, the manas grasps the base consciousness as something internal to the self. The intelligence thus has a body, and assumes this to be its center of thought. It begins to distinguish between "here" and "there." Then, the consciousness, considering the body to be real, gives rise to the distinction between the self and those things attached to the self (wo wosuo 我我所). Following on from this, the first six consciousnesses divide and combine different things in the environment: this flower, the wasp, this hand, the wasp which is first at the flower and then is by the hand, then material objects, space, time — all of these "burning lamps" (chiran 熾然) $)^{88}$ appear to oneself. Analysis of these material things from a distance leads to the establishment of different points in time, small particles, and material things such as molecules, atoms and electrons. Although Einstein's theory of relativity is impoverished and incomplete, it is in agreement with Yogācāra. ${ }^{89}$

Taixu's interpretation therefore emphasized the similarities between relativity and Yogācāra, while claiming that the theory of relativity lacked Yogācāra's level of comprehensiveness. He could therefore invoke Einstein — whom he called "the greatest contemporary scientist" support of Yogācāra, while showing his ideas to be inadequate when compared with Buddhism.

\footnotetext{
${ }^{88}$ Ibid., s.v. “chiran 熾然,” by C. Muller (accessed March 25, 2012).

${ }^{89}$ Taixu, “Ai'ensitan xiangduilun yu weishilun,” pp. 617--618.

${ }^{90}$ Ibid., p. 616.
} 
In 1937, Taixu again referred to contemporary scientific literature in some detail with the intention of showing how Yogācāra accorded with new scientific developments. ${ }^{91}$ The basis of his discussion was a speech given by the British physicist Sir James Jeans (Qinsi Jueshi 秦斯爵 士). Entitled “The New World Picture of Modern Physics," this originally appeared in a 1934 issue of the journal Science. It appeared in Chinese translation in Eastern Miscellanies in $1937 .{ }^{92}$ Jeans's speech had focused on what he called "the new physics." He declared that the old physics was akin to a mansion that had been shaken by a series of earthquakes. The principles of physics could "only be made comprehensible in the form of parables," and "no parable can remain true throughout its whole range to the facts it is trying to explain.... The fundamental mistake of the old-fashioned physicist was that he failed to distinguish between the half-truths of parables and the literal truth." ${ }^{.93} \mathrm{He}$ added that space and time were "mere mental frameworks of our own construction. ${ }^{" 94}$ Casting doubt on the reliability of sensory perception, Jeans explained:

${ }^{91}$ See Taixu, “Xin wulixue yu Weishixue 新物理學與唯識學 (The New Physics and Yogācāra),” in TDQS, vol. 21, 2005 [1937], pp. 596-618.

${ }^{92}$ Qinshi Jue (Sir [James Hopwood] Jeans), “Xiandai wulixue de xin shijieguan 現代物理學的 新世界觀” (The New World Picture of Modern Physics), trans. Tang Zhongling 湯鍾靈, Dongfang zazhi 34, no. 6 (1937): 65-77; James Hopwood Jeans, “The New World-Picture of Modern Physics," Science 80, no. 2071 (September 7, 1934): 213-222.

${ }^{93}$ Ibid., p. 214.

${ }^{94}$ Ibid., p. 215. 
Physical science, assuming that each message must have had a starting point, postulated the existence of "matter" to provide such starting points. But the existence of this matter was a pure hypothesis; and matter is in actual fact as unobservable as the ether, Newtonian force, and other unobservables that have vanished from science. Early science not only assumed matter to exist but further pictured it as existing in space and time. Again, this assumption had no adequate justification; for there is clearly no reason why the whole material universe should be restricted to the narrow framework along which messages strike our senses. To illustrate by an analogy, the earthquake waves which damage our houses travel along the surface of the ground, but we have no right to assume that they originate in the surface of the ground; we know, on the contrary, that they originate deep in the earth's interior. ${ }^{95}$

As a result, "the whole picture, and the manifold dimensions of space in which it is drawn, become pure mental constructs-diagrams and frameworks we make for ourselves to help us understand phenomena." 96

Such comments led Taixu to conclude that since nineteenth-century physics was deficient, the only remaining option was to renovate it using the tools provided by Yogācāra. When Jeans stated that scientific truths could be expressed only through the use of metaphors, Taixu claimed this was akin to the difference between the posited reality (anlidi 安立諦)一 the attempt to express truths about reality using language—and unposited reality (fei anlidi 非安立諦), or ultimate truth. Similarly, Jeans's example of our inability to directly sense the origin of an
95 Ibid., p. 215.
${ }^{96}$ Ibid., p. 217. 
earthquake was akin to perceptions that travelled through our sensory organs, but whose origins — in the base consciousness — we were unaware of. ${ }^{97}$ Finally, the notion that reality was a mental construction - and, as Jeans stated in his speech, the inability to distinguish between objective and subjective reality_-meant that science had, as Taixu predicted, finally verified the existence of the base consciousness. Scientists were therefore realizing what Yogācāra scholars already knew: that "the world of external objects and the views of the internal mind are of the same nature."98

\section{Taixu and Cassirer}

In 1929, Taixu gave a speech entitled "The Person of Culture and the Base Consciousness." ${ }^{99} \mathrm{He}$ recalled encountering the idea of the "person of culture" (wenhuaren 文化人) on the German leg of his Euro-American tour in 1928 and 1929. Although he did not provide the source of this idea - he may not have known - it would appear that he was referring to Philosophy of Symbolic Forms, the three volumes of which the German philosopher Ernst Cassirer (1874-1945) published in 1923, 1925, and 1929. The speech indicates that Taixu was not only interested in responding to science from the perspective of Yogācāra but that he also saw it as a useful vantage point from which to approach Western thought more generally, including contemporary European philosophy.

\footnotetext{
${ }^{97}$ Taixu, "Xin wulixue yu weishixue," p. 600.

${ }^{98}$ Ibid., p. 602.

${ }^{99}$ Taixu, “Wenhuaren yu alaiyeshi 文化人與阿賴耶識” (The Person of Culture and the Base Consciousness), in TDQS, vol. 20, pp. 237-242.
} 
Cassirer held that culture manifested in various "symbolic forms" throughout history, including "myth, religion, language, science, [and] art." ${ }^{100} \mathrm{He}$ emphasized the creative power of the individual to make history, against what he called the "physicalist" determinism of Comte, the "psychological" determinism of Spengler, and the "metaphysical" determinism of Hegel. ${ }^{101}$ In contrast to Kant, Cassirer held that 'there is no 'primary datum' underlying the creative activity of consciousness. Every primary datum is already spiritually imbued, even the simplest spatial perceptions, like left and right, high and low." ${ }^{102}$ Therefore, "the question [of] what absolute reality should be outside that totality of spiritual functions, what the 'thing in itself' might be in this sense ... [is] a falsely put problem, a phantom of thought." ${ }^{103}$ Cassirer instead compared human beings to artists; interaction with the environment was creative and imbued it with meaning. ${ }^{104}$ It was recognition of one's own creative power, and the manipulation of symbolic formations, that would enable humanity to become liberated from them. Thus, "a healthy consciousness must in every act, shuttle back and forth throughout the aeons of cultural development and knit all of them into the act." ${ }^{105}$ In advocating a complex, ever-changing conception of culture, and a human integration with its products that led to ultimate liberation,

\footnotetext{
${ }^{100}$ Enno Rudolph, "Symbol and History: Ernst Cassirer's Critique of the Philosophy of History," in The Symbolic Construction of Reality: The Legacy of Ernst Cassirer, ed. Jeffrey Andrew Barash (Chicago: University of Chicago Press, 2008), p. 7. Here, Rudolph is summarizing Hans Blumenberg.

${ }^{101}$ Ibid., p. 12.

${ }^{102}$ Robert S. Hartman, "Cassirer's Philosophy of Symbolic Forms," in The Philosophy of Ernst Cassirer, ed. Paul Arthur Schilpp (Evanston, IL: Library of Living Philosophers, 1949), p. 293.

${ }^{103}$ Ernst Cassirer, Philosophie der symbolischen Formen, I, 47 f., cited in Hartman, "Cassirer's Philosophy of Symbolic Forms,” pp. 294-295.

${ }^{104}$ Ibid., pp. 300-301.

${ }^{105}$ Ibid., p. 305.
} 
Cassirer "points toward a future of symbolic forms so rich that man's present culture appears very primitive indeed."106

Taixu augmented various aspects of this theory with concepts from Yogācāra. In agreement with Cassirer, he explained that "the person of culture has two aspects: one is historical, and one is social." ${ }^{107}$ While people bore the legacy of their cultural past; this could be the foundation on which to build a new, superior culture. ${ }^{108}$ However, he diverged from Cassirer when he added that the person of culture - which he also called the "universal person" (yuzhouren 宇宙人)—should be subject to a “Buddhist education." 109

Taixu explained it was the base consciousness that determined interpersonal differences; this was how unique individuals such as Confucius and the Buddha could appear. ${ }^{110}$ The influence of environmental factors on Confucius's and the Buddha's base consciousness led them to become exemplary individuals. Taixu saw the cultural person as one who could "absorb the common qualities of the world" and yet also develop the "uncommon qualities" that made them unique and stand above others (like Confucius and the Buddha). ${ }^{111}$ By supplying the right influences, the base consciousness could therefore be deliberately molded.

Taixu delivered another speech the next year-one that provided readers with a summary of what a Buddhist education might entail. He explained that the concepts of "nonself" and

\footnotetext{
${ }^{106}$ Ibid., p. 332.

${ }^{107}$ Taixu, "Wenhuaren yu alaiyeshi," p. 237.

${ }^{108}$ Ibid.

${ }^{109}$ Ibid., p. 239.

${ }^{110}$ Ibid., pp. 241-242.

${ }^{111}$ Ibid, p. 242.
} 
"nothing but mind" should form the basis of a universal worldview. ${ }^{112}$ As was the case with science, Taixu saw much that was of value in the person of culture, but the fact that the concept was so compatible with Yogācāra was evidence of its veracity. He did, however, continue to present Buddhism as a superior overarching framework in which Cassirer's theory would need to be situated in order to render it complete. Taixu's person of culture can also be read alongside his critique of Liang Shuming's promotion of Confucian culture (which Thierry Meynard discusses in this volume), because Buddhism could encompass the best of Liang's cultural typologies while remaining true to itself as a superior worldview and the pinnacle of modernity.

\section{Conclusion}

Taixu features prominently in histories of Chinese Buddhism, but less so in intellectual histories of modern China. He was, of course, a monastic, and throughout his life he was committed to the promotion of a Chinese Buddhist worldview. Yet he also maintained a broad engagement with China's republican intellectual scene, to which he contributed from his Buddhist perspective. Perhaps he has been difficult to place as a historical figure because he was such a divisive figure in the Buddhist world (his ideas were far from universally accepted) and was not a secular intellectual. Although he did not fit in either camp, as the chapters in this volume show, the boundary between the secular and the religious was permeable for other late-Qing and republican intellectuals as well. ${ }^{113}$ When we consider Yogācāra's role in bridging these two spheres during

\footnotetext{
112 Taixu, “Cong wuwo weixin de yuzhouguan dao pingdeng ziyou de renshengguan 從無我唯心的宇宙觀到平等 自由的人生觀” (From a Nonself-Mind-Only Worldview to an Egalitarian and Free Outlook on Life), in TDQS, vol. $22(2005$ [1930]), p. 986.

${ }^{113}$ Furthermore, later in Taiwan and the PRC, the nuances of his ideas were rejected by Buddhists in favor of his broad approach to an engaged Buddhism. This is because "Buddhism for the human world," as a general concept,
} 
the period, Taixu's importance as an active agent at the heart of this confluence of trends becomes clear.

Taixu can therefore be considered a republican-era intellectual (rather than just a Buddhist reformer) who contributed to ongoing discussions of modernity from his unique stance in traditional Chinese Buddhism. He was concerned with showing that rather than being superstitious and outmoded, Buddhism was capable of furthering modernist projects more effectively than Western scientific, philosophical, and ideological instruments themselves. In his wide-ranging essays and speeches on diverse subjects that included scientific knowledge and its foundations, as well as society and the individual, Yogācāra played an important part in this critical assessment of modernity. While on the one hand, it was evident through Yogācāra that Buddhism shared important similarities with his conception of Western modernity, on the other, he saw Yogācāra as capable of correcting the deficiencies of modernity. Yogācāra was therefore a crucial aspect of his overall intellectual project in that it helped him articulate a modern Buddhist approach to engaging with Western science, philosophy, and ideology—which he felt was the only viable path for China's future.

had great currency whereas many of his specific ideas did not accord with ideological or scientific developments in the ensuing decades, or were too divisive for broad acceptance. 